\title{
Practical Work: Its Effectiveness in Primary and Secondary Schools in England
}

\begin{abstract}
We report here on the first of two evaluations of a national project (Getting Practical: Improving Practical Work in Science - IPWiS) designed to improve the effectiveness of practical work in both primary and secondary schools in England. This first baseline evaluation of the effectiveness of practical work is based on a study of a diverse range of 30 practical lessons undertaken in non-selective primary $(\mathrm{n}=10)$ and secondary $(\mathrm{n}=$ 20) schools prior to the teachers undertaking a training intervention designed to improve their effective use of practical work. A multi-site case study approach employing a condensed fieldwork strategy was used in which data were collected, using audiotape-recorded discussions, interviews and observational field notes. The analysis, based on work by Millar et al. and Tiberghien, considers what students do and think relative to what their teacher intended them to do and think. In both primary and secondary schools the widespread use of highly structured 'recipe' style tasks meant that practical work was highly effective in enabling students $(\mathrm{n}=857)$ to do what the teacher intended. Whilst tasks in primary schools tended to be shorter than in secondary schools, with more time devoted to helping students understand the meaning of new scientific words, neither primary nor secondary teachers' lesson plans incorporated explicit strategies to assist students in making links between their observations and scientific ideas. As such, tasks were less effective in enabling students to use the intended scientific ideas to understand their actions and reflect upon the data they collected. These findings suggest that practical work might be made more effective, in terms of developing students' conceptual understanding - an aim of the IPWiS project - if teachers adopted a more 'hands-on' and 'minds-on' approach and explicitly planned how students were to link these two essential components of practical work.
\end{abstract}

Keywords: practical work; effectiveness; conceptual understanding

\section{Introduction}

Practical work is widely and frequently used in the teaching of science in English secondary schools (Bennett, 2003; Millar, 2004). A likely reason for this, as Donnelly (1998) has suggested, is that many science teachers see the frequent use of practical work as an essential part of what it means to be 'a science teacher'. That practical work "seems the 'natural' and 'right' thing to do" (Millar, 2002 p. 53) means that many teachers see its use as the basic modus operandi for the teaching of science. Indeed, there is a common perception amongst teachers in England that the use of practical work can motivate students towards the study of science (Wellington, 2005). This presents a risk that for many teachers the use of practical work can become so routine that they cease to assess critically whether it is always the most effective way of achieving a specific learning outcome.

We emphasise here that we use the term 'practical work', as it is commonly used in the European science education literature, as an overarching term that refers to any type of science teaching and learning activity in which students, working either individually or in small groups, are involved in manipulating and/or observing real objects and materials (e.g. determining which of a selection of objects are magnetic, carrying out and observing flame tests) as opposed to virtual objects and materials such as those obtained from a DVD, a computer simulation, or even from a text-based account (Millar, 2011). Practical work in this sense is a broad category that includes, for example, 'recipe' (Clackson \& Wright, 1992) style tasks (sometimes referred to as 'cook-book' tasks), 'experiments', investigations and discovery style tasks. In characterising such activities not on the basis of where they are 
undertaken but on what is undertaken, it seems more appropriate to refer to them as 'practical work', rather than 'laboratory work' (or 'labwork'). That said, we recognise that in many countries, including England, most secondary school science practical work is undertaken in purpose-built laboratories (White, 1988) and so most of what we refer to as 'practical work' can also be thought of as being 'laboratory work'. Whilst open-ended investigations, in which students have a greater degree of freedom in deciding what and how to investigate, do occur, the 30 practical lessons observed in this study were all 'recipe' style tasks in which students generally work alongside each other following teacher and task instructions (Kind et al., 2011). The prevalence of 'recipe' style tasks appears to reflect a combination of the relatively short nature of most practical lessons (about an hour) and the fact that the use of open-ended tasks presents teachers with greater pedagogical challenges (Hofstein \& Lunetta, 2004) than do traditional recipe style tasks. This is not to say that open-ended investigations might not be more effective, for example in developing the ability to formulate appropriate scientific arguments (Richmond \& Striley, 1996), but rather that the skills that such open investigations develop are not sufficiently recognised in the current assessment criteria and, as Donnelly et al. (1996) have reported, teachers' preferences for using different types of practical work are influenced by their considerations of curriculum targets and methods of assessment.

Students also see practical work as being both affective and effective in terms of their learning and enjoyment of science. In a survey (Cerini et al., 2003) of over 1400 students in England (of a range of ages) it was found that $71 \%$ chose 'doing an experiment in class' as one of the three methods of teaching and learning science they found 'most enjoyable' and $38 \%$ claimed it as one of the three methods of teaching and learning science they found 'most useful and effective'. In both cases, this placed it third in rank order. Yet, despite these findings, a number of science educators (Abrahams \& Millar, 2008; Hodson, 1991; Osborne, 1993; Wellington, 1998) have raised questions about its effectiveness.

Research findings into the effectiveness of practical work in enhancing the development of conceptual understanding in science remain ambiguous. Hewson and Hewson (1983) report a significant enhancement of students' conceptual understanding amongst that half of their study group, of students aged 13-20, who had received a primarily practical-based instruction compared to the other half of the study group that had received a traditional non-practical instruction. However, in other comparable studies such findings have not been duplicated. Indeed, Mulopo and Fowler (1987), in a study of 120 grade 11 students studying chemistry, reported no significant difference in the level of conceptual understanding amongst students whether they had been taught using practical or traditional non-practical methods. Furthermore, reviews relating specifically to practical work (Hofstein \& Lunetta, 1982; Lazarowitz \& Tamir, 1994) have all concluded, when outcomes are measured using pen and paper tests, that the use of practical work offers no significant advantage in the development of students' scientific conceptual understanding.

It is true that, as Hofstein and Lunetta (1982) observe, "Many of these studies have reported nonsignificant results, meaning that the laboratory medium was at least as effective in promoting student growth on the variable measured as were more conventional modes of instruction" (p. 212). However, given the central role of the laboratory in the science curriculum and its relatively high financial cost, these non-significant findings, corroborated by further recent studies (Burron et al., 1993; Chang and Lederman, 1994; Jackman and Moellenberg, 1987; Watson et al., 1995), are at best disappointing. Clackson and Wright (1992, p. 40) succinctly summarise the situation thus: "Although practical work is commonly considered to be invaluable in science teaching, research shows that it is not necessarily so valuable in science learning". Indeed, Hodson (1992) has claimed that it is necessary to introduce the students to the relevant scientific concepts prior to their undertaking any practical work if the task is to be effective as a means of enhancing the development of their 
conceptual understanding. Furthermore, Millar (1998) has questioned whether the observation of specific phenomena within the context of a practical task can, unaided, lead to the development of conceptual understanding. In this context it has been proposed (Millar et al., 1999) that the function of practical work might be better understood in terms of a link, or bridge, between previously taught scientific concepts and subsequent observations.

Therefore, despite the frequent claims that one of the aims of practical work is to provide an effective means of developing conceptual understanding the research findings suggest, at least when the outcomes are measured using pen and paper tests, that there is no significant advantage to its use. Indeed, despite the widespread use of practical work in many countries, Lunetta et al. (2007) have suggested that "Much more must be done to assist teachers in engaging their students in school science laboratory experiences in ways that optimize the potential of laboratory activities as a unique and crucial medium that promotes the learning of science concepts and procedures, the nature of science, and other important goals in science education" (p. 433). The IPWiS (Getting Practical: Improving Practical Work in Science) project was developed to contribute towards just such an improvement in the quality and effectiveness of practical work in English primary and secondary school science.

The research question that this baseline phase of the evaluation sought to answer was: How effective is practical work in both primary and secondary school science, as it is actually carried out, as a teaching and learning strategy prior to any of the teachers observed undertaking the IPWiS training?

\section{A Framework for Considering the Effectiveness of Practical Work}

Practical work encompasses a broad range of activities that can have widely differing aims and objectives (Lunetta \& Tamir, 1979). As such, it is the effectiveness of specific practical tasks, rather than the effectiveness of practical work in general, that needs to be considered. The analytical framework used here to determine the effectiveness of practical work is one that was developed and used by Abrahams and Millar (2008) in a previous study of the effectiveness of practical work. It draws on a model (Figure 1), proposed by Millar et al. (1999), for evaluating a practical task. This model considers the effectiveness of a specific task relative to the aims and intentions of the teacher and, as such, the starting point (Box A) is an evaluation of the teacher's learning objectives in terms of what it is they want the students to learn. After deciding what they want the students to learn the next step (Box B) is for the teacher to design a specific practical task that, they believe, has the potential to enable the students to achieve the desired learning objectives. As the students might not do exactly what was intended by the teacher, the next step (Box C) considers what it is that the students actually do as they undertake the task. There are various reasons as to why the students might not actually do what their teacher intended; for example, they might not understand the instructions or, even if they do and adhere to them meticulously, faulty apparatus can prevent them from doing what was intended by the teacher. Alternatively, even if the task is carried out as the teacher intends and all of the apparatus functions as intended, the students still might not engage mentally with the task using the ideas that the teacher had intended them to use.

\section{Figure 1 GOES HERE}

The final stage of the model (Box D) is thus concerned with what the students learn as a consequence of undertaking the task. This model allows the question of the effectiveness of a specific practical task to be considered at two separate levels. We can consider the 
effectiveness of the task (at level 1) in terms of the match - or alignment - between what the teacher intended students to do and what they actually do and the effectiveness of the task (at level 2) as being the match - or alignment - between what the teacher intended the students to learn and what they actually learn. 'Level 1 effectiveness' is therefore concerned with the relationship between Boxes B and C in Figure 1, while 'level 2 effectiveness' is concerned with the relationship between Boxes A and D. We emphasise that the effectiveness of practical work developed in this model is not framed solely by what students do or learn, nor by what their teachers expect, but rather by comparing what students actually do and learn relative to what their teachers intended them to do and learn. In effect, the extent of the alignment between what the teacher intends students to achieve, through the use of a specific practical task, and what they actually achieve is what we mean by the effectiveness of that task in achieving the learning objectives set by the teacher. Therefore, even if unplanned spontaneous learning (desirable or not) takes place in a practical lesson, such learning cannot be considered effective since, by definition, the teacher did not intend for such learning to occur. Evidence for learning, at both levels, was obtained by observing what students did during a task as well as how they respond to questions posed by both the teacher and the researcher during the observed practical lesson. Whilst we acknowledge that such evidence does not provide incontrovertible evidence for students having leant and understood what their teacher intended it is, nevertheless, the same evidence gathering process that experienced science teachers use on a day-to-day basis as part of any Assessment for Learning (Black and Wiliam, 1998) exercise.

This model can therefore be used to address the two following questions:

1. Does the practical task enable the students to do the things the teacher intended them to do?

2. Does the practical task enable the students to learn what their teacher intended?

By combining this two level model of effectiveness with a two domain model of knowledge developed by Tiberghien (2000), in which there is a domain of observable objects and events (o) and a domain of ideas (i), it becomes possible to consider each of the two levels of effectiveness in terms of these two distinct domains.

These two levels of effectiveness, each of which can be considered with respect to the two distinct domains of knowledge, can be represented (Table 1) using a $2 \times 2$ effectiveness matrix.

\section{Table 1. GOES HERE}

The effectiveness of any practical task can now be analysed and discussed in terms of two principal levels with each level being further divided into two domains. To illustrate the use of a $2 \times 2$ effectiveness matrix, consider its application to a practical task that was observed in which students study chromatographic separation of colours in dyes (Table 2).

\section{Table 2 GOES HERE}

The four cells of Tables 1 and 2 are not independent as a task is unlikely to be effective at level 2:i unless it was also effective at levels 1:i, and, most likely, also at levels 1:o and 2:0. Such a framework provides an effective means of evaluating the effectiveness of any practical task in terms of the four cells of Table 1. 


\section{Research Strategy and Methods}

In contrast to previous large-scale questionnaire-based studies of practical work in English and Welsh secondary schools that examined teachers' views (Abrahams \& Saglam, 2009; Beatty \& Woolnough, 1982; Kerr, 1964), this study sought to explore the reality of practical work as undertaken by students. The strategy it used was designed to bring the researchers into contact with teachers and students as they undertook practical work by collecting data in the teaching laboratory and focusing on observation of actual practices augmented by discussions with the students conducted in the context of these observations along with short pre- and post-observation interviews with teachers.

The study used a series of 30 case studies in different settings which, in scale, were similar to those undertaken by Firestone and Herriott (1984) and Stenhouse (1984). The use of this approach had the advantage that it avoids what Firestone and Herriott (1984) refer to as the disadvantage of 'radical particularism' that is associated with the traditional single indepth case study. Whilst an in-depth case study has the advantage of high ecological validity (Bracht \& Glass, 1968), its Achilles' heel is its relatively low population validity (Cohen et al., 2000). Population validity, like ecological validity, can enhance or threaten the external validity of a study and refers to the extent to which it is possible to generalise from the research findings, obtained from a relatively small sample population, to members of a much larger population (Bracht \& Glass, 1968; Cohen et al., 2000). It has been suggested (Crossley \& Vulliamy, 1984; Shaughnessy \& Zechmeister, 1985) that the use of a single case study is open to criticism on the grounds that it might not be representative of the population to which subsequent generalisations may wish to be made.

It was therefore decided to use a multi-site case study approach that employed a 'condensed fieldwork' strategy (Walker, 1980 p. 43). As the term suggests, 'condensed fieldwork' means that only a short period of time is spent at each site. The advantage of a multi-site case study approach with a condensed fieldwork strategy is that it provides an opportunity not only to achieve a high degree of ecological validity but also to raise the population validity of the study, thus enhancing the external validity of the study and, as such, the extent to which findings can be generalised to a larger population.

Written permission was obtained from 30 schools: ten primary (students aged 5-11 years) and twenty secondary (students aged 11-18 years) - from a sample of two hundred schools that had signed up to the IPWiS project - to observe one practical lesson before and another after the IPWiS training. As a group these schools were typical, in terms of size and geographical location, of primary and comprehensive secondary schools in England with the sample consisting of three rural and seven urban primaries and eight rural and twelve urban secondary schools. The average class size across all 30 classes within the sample was 29 students (see Tables 3 and 4 for number of students in each class). The classroom teaching experience of both the primary and secondary teachers in the study ranged from newly qualified, i.e. one year in the classroom, to teachers with over 25 years classroom experience. Likewise, with regards to secondary teachers, all three secondary science main subject specialisms (biology, chemistry, and physics) were represented. Some of the characteristics of the schools and teachers - the identities of which been replaced with codes to preserve anonymity - are presented in Tables 3 and 4. The selection of schools was principally concerned with ensuring what Ball (1984) refers to as "naturalistic coverage" (p. 75) and the pragmatic concerns of gaining access which, in England, is becoming increasing difficult, rather than with meeting more rigorous sampling requirements associated with traditional quantitative research. 


\section{Table 3 GOES HERE}

\section{Table 4 GOES HERE}

Whilst we had no control over the subject matter, or age of the students (beyond their being in primary or secondary schools) a reasonably balanced coverage of subject material and age ranges was achieved in the lessons observed. It was noted that the lesson observations later in the sequence of observations appeared to raise the same generic issues as earlier ones, suggesting that data saturation had been achieved by that point.

To evaluate the effectiveness of practical work at both levels and across both domains meant that data had to be collected on what students did and learnt as well as what the teacher intended them to do and learn. To do this an effectiveness matrix (an example of the one used in school SAS is shown in Table 2) was constructed prior to a lesson observation to enable each researcher, in the limited time available, to quickly and clearly evaluate - and corroborate their evaluation from a subsequent analysis of the transcripts - the effectiveness of each task in terms of the four cells of Table 1. In addition, digitally-audio-recorded interviews (see Appendix A) were carried out with the teacher before and after the lesson observation in order to obtain information relating to their views on practical work in general and the specific lesson being observed. In particular, the researchers sought details of the intended learning objectives and outcomes of the lesson prior to the observation so that an evaluation of the effectiveness of the lesson could be made by comparing what the teacher said they intended with the observed reality using the framework described above. Ethnographic field notes were also made and while these are mostly descriptive (i.e. 'factual'), there are occasions when our field notes include our interpretations; indeed, all ethnography entails some element of interpretation, if only interpretation of what to note. However, we have ensured that it is clear when our field notes are descriptive and when interpretative. In addition to digitally-audio-recording all teacher-whole class discussion and instructions - which provided information on how time was allocated to various tasks within each lesson - conversations between groups of students, and between students and the researcher, were also digitally-audio-recorded. These conversations, when combined with the field notes, provided insights into the students' thinking not only about the task that they were observed undertaking - and in particular what they understood as a result of undertaking the task - but also with regards to their recollections of previous practical tasks that they had undertaken.

Each lesson was observed by one of three researchers (each, prior to their current role, having been an experienced teacher/head of department - two in secondary schools and the third in a primary) with the number of observations being split 7:10:13. Of the thirty lessons three were co-observed as part of a process to improve the 'trustworthiness' of the qualitative findings. Within a lesson observation of about an hour (the opportunity to move around the laboratory and talk to the students was frequently less than this) it was not possible, nor desirable, giving the dynamic nature of the lesson to ask each and every student (with an average of 29 students per class) the same questions. This study used a similar approach as with teacher-based formative Assessment for Learning (Black \& Wiliam, 1998; Coffey et al., 2011) in which teachers make informed judgements on the learning within a lesson - without asking the same question to each and every student within a class. As such, whilst some students, in the same class, were asked the same questions, others were asked different ones by the researcher as they moved around the class observing and recording what students were doing and saying as they undertook the practical task. The claims we make about a particular issue are therefore a composite image based on the combined responses of each subset of students - the size of which varied - within all of the lessons observed, who were asked the 
same or similar questions as well as post-lesson interviews with the teachers. In this respect although it is possible that the three to four students in a class who were typically asked a particular question might have been atypical of their class as a whole, that this would be the case in most of the 30 classes is unlikely. Indeed, in one particular case, where the researcher was uncertain that four students, who claimed not to know the meaning of a key word in the lesson, could really be representative of the class as a whole, all 25 remaining students were asked the same question at the end of the lesson and only two were found to know what the word meant. It therefore appears reasonable to assume that common themes or patterns that repeatedly emerged when students in different schools were questioned about practical tasks are representative of the sample as a whole.

The design of the study and the fact that it was impractical to administer pre- and posttests for such a wide range of topics meant that it was not feasible formally to test the students' understanding of observables or ideas that the practical lessons were designed to develop. As such. evidence of effectiveness at level 2 was obtained during the lesson by questioning almost all of the students in each class to assess whether they were able to describe what they did with objects and material (2:0) and to explain their observations and/or data using the scientific ideas (2:i) intended by the teacher. Evidence for the effectiveness of each lesson, recorded in field notes during the lesson, was verified for a second time through an analysis of the transcripts and teacher lesson plans by a researcher who had not observed that lesson again using the same $2 \times 2$ matrix.

Similarly, the fact that access into schools was limited to one pre-IPWiS training visit meant that there was no opportunity to assess any change - and in particular possible improvement - in the students' proficiency with equipment and/or their ability to carry out similar tasks as a result of what they had learnt in the task that was observed. We recognise that this means that we can say much less about the effectiveness of practical tasks at level 2 than at level 1. Our judgements about effectiveness at level 2 are therefore based on what the students said when questioned during, or immediately after, the completion of a practical task about what they had learnt in that lesson as well as in previous (unobserved) practical lessons. We point out that whilst we remained open to the possibility that students might manifest spontaneous learning, any such learning could not, within the framework we used, be considered as evidence for level 2 effectiveness within that lesson.

\section{Findings and Discussion}

\section{Introduction}

The analytical framework in Table 1 was used in analysing the data, and will also be used here to structure the discussion. This framework enabled the researchers to ascertain, through their observations, what the students did with objects and materials compared with what the teacher intended and, as such, how effective the practical task had been at level 1:0. Likewise, by comparing what the teachers intended their students to learn, as stated in their pre-lesson interviews, and as evidenced in their lesson plans, with the comments made by the students during the lesson, it was possible to evaluate, in a qualitative sense, the extent to which effectiveness at levels 1:i, 2:0 and 2:i had been achieved. We wish to emphasise three points before proceeding further. First, in reporting on the effectiveness of specific practical task our claims relate to the extent to which what the students did and learnt, whilst undertaking a specific task, what their teacher intended them to do and learn (cf. Abrahams \& Millar 2008; Millar \& Abrahams, 2009). Second, evidence of what students learn, obtained by class teachers in lessons as part of Assessment for Learning (Black \& Wiliam, 1998) is, as it is in this study, based on a range of assessment tools including observations of what students did in the lesson and what they said when talking amongst themselves, to the teacher 
and to the researcher. Third, in every one of the 30 lessons observed there was almost no discussion of specific points about scientific enquiry in general, nor any examples of use by the teacher of data obtained by students to draw out general points about the collection, analysis, and interpretation of empirical data. In many lessons there were clear opportunities to do this, yet these were not exploited. As such, our focus in the discussion that follows does not deal with these issues, not because our framework was unsuitable, or excluded these aspects of learning, but simply because the reality of the practical work observed in these lessons - in contrast to what we might believe teachers ought to be doing (given all that has been written on practical work) - did not include these features.

Throughout the remainder of this article teachers are referred to by a three letter code that identifies their school (Tables 3 and 4) along with a forth letter - a ' $p$ ' or an 's' - to indicate whether the school was primary or secondary. So, for example, WAEp refers to a primary teacher at a school identified as WAE. Students are identified using their teacher's identification code followed by a number so, for example, WAEp1, WAEp2, and WAEp3 would refer to three students in a lesson at the secondary school WAE. All examples chosen to illustrate classroom practices are representative in the sense that they are typical rather than unusual.

We start by considering the effectiveness of tasks at level 1, that is, in getting students to do what the teacher wanted them to do with objects, materials and ideas. We then go on to consider effectiveness at level 2, which relates to the effectiveness of the practical task in getting the students to learn what the teacher wanted about objects, materials and ideas.

\section{Doing with Objects, Materials and Ideas (Effectiveness at levels 1:o and 1:i)}

Before proceeding further, it is useful to briefly re-visit the distinction we made earlier between doing with objects and materials and doing with ideas. Doing with objects and materials refers to the physical action of manually engaging with objects such as ammeters, magnesium ribbon or microscope slides and it is, quintessentially, the 'hands-on' part of 'practical work'. Evidence for effectively doing with objects and materials (effectiveness 1:0) is obtained during the lesson by observing what students do with the objects and materials provided and comparing this to what the teacher informed the researcher, prior to the lesson, that they wanted the students to do with those objects and materials. Doing with ideas is essentially the mental process (as operationalized and evidenced through conversations between a student and other students, their teacher, or the researcher) in which students think about the practical task using appropriate scientific ideas, as in when a student talks about an electric current as the flow of charge, or the voltage as being the 'push' of a battery. Although it might be argued that such 'utterances' are not necessarily evidence for learning we suggest that experienced teachers do make use of such utterances on a daily basis as a means of assessing learning and understanding. Like experienced teachers we too recognise that not all utterances are synonymous with 'doing with ideas' as, for example, when a student talks about the readings on a Newton meter simply in terms of the position of a pointer on a scale rather than as a measure of an applied force.

All of the practical work observed was effective in the sense that it enabled the vast majority of students in each class to successfully do with the objects and materials what the teacher intended. Various factors contributed to this including the widespread use of 'recipe style' (Clackson \& Wright, 1992) tasks and the fact that in many of the lessons observed, teachers devoted considerable time (Tables 5 and 6) and effort on ensuring that students understood the procedure they wanted them to follow and had sufficient time to generate the phenomenon and/or data. As one teacher (AREs) explained to the class: “... we've got a 50 minute lesson, right, say we're going to do this practical, we need to do this, this, this, get on 
with it." Two other secondary teachers made similar points about their using 'recipe' style tasks to ensure that within a typical practical lesson most of their students would successfully be able to set up the apparatus, produce a particular phenomenon, and record and analyse the results.

\section{Table 5 GOES HERE}

\section{Table 6 GOES HERE}

Whilst the average proportion of the lesson time devoted to procedural instruction by secondary teachers $(17 \%)$ appears slightly higher than that devoted by primary teachers (13\%) a Mann-Whitney $U$ test carried out between both groups of teachers shows there to be no statistically significant difference $(\mathrm{m}=10, \mathrm{n}=20, \mathrm{U}=142 \mathrm{p}>0.1$, two-tailed $)$. A similar Mann-Whitney $U$ test applied to the proportion of lesson time devoted by both primary and secondary teachers to 'doing with objects and materials' shows there to be a statistically significant difference $(\mathrm{m}=10, \mathrm{n}=20, \mathrm{U}=164, \mathrm{p}<0.01$, two-tailed $)$. Furthermore, when a Mann-Whitney $U$ test was carried out on the proportion of lesson time devoted by primary and secondary teachers to 'doing with ideas' it showed there was a highly significant difference ( $m=10, n=20, U=195, p<0.0001$, two-tailed) between the groups.

Despite the limitation that Tables 5 and 6 only present details on the time spent on 'whole class' activities - it was not possible from the transcripts or field notes to ascertain the time spent by the teacher on different kinds of activity when working with small groups or individual students - these data provide an indication of the extent of the imbalance between the amounts of time spent supporting 'doing with objects and materials' and 'doing with ideas'. Indeed, what emerges from Tables 5 and 6 is that the reduced amount of time primary teachers allocate, on average, to undertaking the task, compared with their secondary colleagues, is allocated to 'doing with ideas'.

Given that the effectiveness of a practical task in all the other cells of Table 1 arguably depends on its being effective at level 1:0, the allocation of a similar proportion of wholeclass lesson time in both primary and secondary schools to procedural instructions might be neither unexpected nor unwarranted. However, if the effective production of a phenomenon and/or collection of data become the sole aim of a practical lesson then the potential teaching and learning value of practical work is substantially diminished. Indeed, as Edmondson and Novak (1993) noted, a focus on simply completing the task within the lesson can overwhelm any serious opportunity for conceptual learning to occur. What emerged in this study, as the following example illustrates, was that some tasks were observed to be little more than the unquestioning adherence to a 'recipe' in order to produce a phenomenon and/or data.

CANs17: Yeah, so I'm just following the method that we've been given [indicates worksheet] and hopefully ... and we've got like the results table [points to pre-printed table on the worksheet] so we'll just get them [their results] down.

Whilst 'doing with objects and materials' is self-explanatory, 'doing with ideas' is less self-evident. It refers to the process of thinking and talking about objects and materials, using scientific terminology and theoretical entities or constructs that are not themselves directly observable. Since thinking is itself not directly observable, claims about student thinking and learning are inferred from their comments made during the lesson. 
Getting students to think about objects and materials using particular scientific ideas can be difficult as these ideas do not present themselves directly to students' senses. Furthermore, some scientific words associated with these ideas can be unfamiliar and/or 'strange', e.g. inertia, kinetic, photosynthesis and titration, or, whilst familiar, have alternative, well established, non-scientific meanings, e.g. force, work, cell and organic. Almost all the lessons observed (Table 3 and 4) provided students with the opportunity to think about observables using scientific terminology and/or scientific ideas.

Four of the eight primary teachers who were not science-specialist primary teachers spoke to the researchers about their own difficulties in understanding scientific ideas and the meaning of certain scientific terms as well as, in some cases, a lack of confidence in teaching science (cf. Appleton, 1995; Harlen \& Holroyd, 1997). As a consequence of their own difficulties with some aspects of science, most appeared better able to empathise with the difficulties that their students faced when learning about new ideas and the meaning of new scientific terms than were many secondary subject specialists (Abrahams \& Reiss, 2010). Indeed, one consequence of this was the fact that, on average, primary teachers as a group allocated more whole-class time to 'doing with ideas' (Tables 5 and 6) which, in many cases, meant devoting the time to the use and understanding of scientific words than did secondary teachers. In one particularly notable case, a primary teacher SOSp allocated a substantial amount of whole class time to getting students to practise the pronunciation of ten new scientific words, discuss their meanings within small groups, and then share tips with the rest of the class about how they might successfully remember what these words meant. In contrast, secondary teachers, on average, devoted less time to 'doing with ideas' - other than ANOs who was a physicist teaching 17-18 year-old students about electric motors and appeared, erroneously in many cases, to assume that because students did not ask them to explain the meaning of any scientific words these words were understood. This lack of understanding on the part of secondary students of key scientific vocabulary is exemplified in the following example in which students, at the end of a lesson, respond to the researcher's question about 'reducing' and 'non-reducing' sugars which had been the focus of the preceding hour long lesson.

Researcher: And what's this Benedict's?

CANs11: It tells you whether it's reducing or non-reducing isn't it?

Researcher: Is it? What's a reducing or non-reducing sugar? [Reading from the worksheet produced by the teacher]

CANs 11: Not that I know to be fair.

Researcher: What's a reducing sugar? [Asking CANs15]

CANs15: I'm not sure.

It can be seen that whilst CANs11 used the terms 'reducing' and 'non-reducing' they did so without any understanding of the scientific meaning of these words that would have been necessary for them to understand their observations using scientific ideas.

In summary, all of the practical tasks, in both primary and secondary schools, were effective in enabling the overwhelming majority of students to do what their teacher wanted them to do with objects and materials. However, due to the fact that secondary teachers gave much lower priority - in terms of the whole-class time they allocated to this - to 'doing with ideas' than to 'doing with objects and materials', they were noticeably less effective in getting students to do with ideas than were primary teachers. Whilst primary teachers allocated a similar proportion of their lesson time to procedural instructions as did secondary teachers, their tasks tended, on average, to be shorter than those used by secondary teachers (Tables 5 and 6). The use of shorter tasks meant that they had more non-practical whole-class 
time to introduce students to the meaning of new scientific terms and, when necessary, scaffold (Wood, Bruner, \& Ross, 1976, p. 90) new scientific ideas, both of which, as Abrahams and Millar (2008) have suggested, are necessary if teaching is to be effective in developing conceptual understanding.

\section{What students learnt about observables and ideas}

The analytical framework presented in Table 1 distinguished between two levels of effectiveness of a practical task. Level 1 related to whether students did the things the teacher wanted, and level 2 is concerned with whether or not they learned the things the teacher intended them to learn. We will now consider the level 2 effectiveness of the lessons observed. The difference between level 1 and level 2 is fairly clear within the domain of observables, in so far as effectiveness at level 1 relates to what students do with objects and materials, whilst level 2 relates to what they learn about the things they have done with the objects and materials involved, and the phenomena they observed. The distinction between effectiveness at levels 1 and 2 in the domain of ideas is more subtle. The distinction here is between, at level 1, being able, during the lesson, to use and engage with scientific terminology and, at level 2, being able to use and show an understanding of the scientific ideas that explain or interrogate the observations and/or data, either during or subsequent to the lesson. Observations of only single practical lessons meant that judgements about effectiveness at level 2 (and particularly 2:i) are based on two types of evidence. In the first instance the researchers sought evidence of short-term learning during the lessons by questioning and listening to the comments made by students as they undertook the tasks in much the same way as experienced teachers do. In the second instance the researchers also asked students, during the observed lesson, about practical work they had undertaken in previous lessons and what had learnt from those tasks. The reason for this was to ascertain not only what they were able to recollect having learnt over the medium- to long-term but whether, as White (1979) has suggested, such recollections provide a memorable event onto which the students are able, by association, to anchor scientific ideas.

When the researchers randomly asked 33 primary and 74 secondary students, during lesson observations, whether they could recollect details of any practical tasks that they had either undertaken themselves, or had observed their teacher demonstrating, they were all only able, unprompted, to recollect a small number (similar findings have recently been reported by Moeed, 2011). Furthermore, the tasks they tended to recollect were in some sense unusual and typically exhibited one or more of the following three characteristics:

1. A distinctive visual, aural, or olfactory component ('flashes, bangs, or smells').

2. A novel context or manner of presentation.

3. A 'gore' factor.

The following example of a task with a distinctive visual (imploding can) and aural (noise of implosion) component was one that two students (aged 13-14) were able to recollect having undertaken. Their recollections were typical in the sense that they tended to involve a brief (although sometimes very detailed) description of what they had done, or had observed their teacher demonstrating, along with other non-scientific details that made the task in some sense 'memorable' to them - in this case, for one student, the fact that it had failed to work. Furthermore, in findings similar to those reported by Hart et al. (2005), this example also illustrates a general finding amongst both primary and secondary students in that they tended to have little, if any, understanding as to why they had undertaken the task, that is its purpose, 
or what they had learnt about the underlying scientific ideas - in this case atmospheric pressure:

Researcher: Can you remember any practicals you've done since you've been at school?

ALYs21: Yeah [talking to ALYs22] do you remember in Year 7 [students aged 11-12], that collapsing can?

Researcher: Collapsing can?

ALYs22: Oh yeah, they put it in something.

ALYs21: And put it in cold water.

ALYs22: Yeah.

Researcher: What did you learn from that?

ALYs21: I don't know, I didn't learn anything, it was just quite funny.

ALYs22: When I did it, it didn't work [implode] for some strange reason.

In terms of effectiveness, it can be seen that the task was ineffective in the domain of ideas at both level 1 and 2 and only partially effective in the domain of observable objects and events.

The fact that the recollections of both primary and secondary students focused on what they had done, or observed being done, in what were for them in some sense 'unusual' practical tasks, supports previous findings (Abrahams \& Millar, 2008) about student recollections. Whilst a student's ability to recollect only a partial description of a practical task does not necessarily imply that the task was ineffective at level 2:i, it does indicate all that the student is able to recollect of having learnt from undertaking that task. The findings of this study would suggest, in contrast to the claim by White (1979) that practical tasks anchor associated scientific ideas, that for both primary and secondary students practical tasks appear primarily to anchor mainly descriptive accounts of what they did and/or saw. This finding might not be unexpected given the substantial amount of whole-class practical lesson time that teachers devote to procedural instructions and ensuring that students are able to successfully do and see a particular phenomenon compared with scaffolding conceptual ideas. We would emphasis here that this does not necessarily imply that practical work could not anchor scientific ideas, as White (1979) has suggested, but only that we found no evidence, within this study, of such anchorage occurring.

Whilst we did not carry out post-observation tests on students to ascertain what they had learnt, our discussions with almost all of the students in all of the 30 lessons about the task being undertaken showed there to be little evidence of learning, in terms of their ability to explain their observations and/or data using the ideas that the teacher intended them to use. We recognise that since a practical task can be a part of a sequence of lessons designed to develop students' understanding of a particular point or topic, teachers might use other, nonpractical, parts of the teaching sequence to develop the links between observations and ideas rather than doing so within the observed practical lesson. That said, no teacher explicitly said, when asked in the post-observation interview about whether the students had learnt what they wanted them to learn, that they actually planned to develop the ideas and learning associated with the practical task in a subsequent lesson. Indeed, many of the intended learning objectives, provided by the teachers in the pre-observation interviews, specifically included the learning of scientific concepts. However, even when a teacher had designed a practical task to develop conceptual understanding it might be unduly optimistic to expect lasting conceptual understanding to be attributable to any single exposure to an idea, however clear or memorable the practical task might be. Indeed, what emerged from the comments made by both primary and secondary students was that there was little evidence of any enduring conceptual understanding that could be clearly attributed to a specific practical task. 
Certainly, whilst some students were able to recollect what they did in previous tasks, there was no evidence of their having understood the task using the ideas that we must presume the teacher intended them to use. Yet it is important to emphasise that learning about ideas can often be an intellectually more demanding task in secondary school science than it is in primary school science, if for no other reason than the concepts involved are more complex. Indeed, 'learning about ideas' in primary school science was often observed to be very similar to 'doing with ideas' in the sense that the former often placed little additional cognitive demand on the student. For example, studying 'forces' would involve primary students 'doing with ideas' in the sense that they would use the scientific word 'force' to describe pushes and pulls. Therefore in terms of their understanding of the concept of a force at this level there is nothing further, in terms of 'learning about ideas', than the idea that a force is a push or a pull that and this simply requires them to be able to think about forces as being 'pushes' or 'pulls'. In contrast, in secondary school the ability to use the word 'force', when describing a push or a pull in a practical task, whilst indicative of effectiveness at level $1:$ i, does not necessarily imply an understanding of the more complex, Newtonian, concept of a force that would be expected for evidence of effectiveness at level 2:i.

\section{Conclusions and Implications}

The aim of this study was to obtain a picture of practical work as it is currently undertaken in primary and secondary school science classes in England. What has emerged is not only a difference between the effectiveness of practical work in the domain of observables and in the domain of ideas, but that primary teachers allocated a statistically significantly larger proportion of the lesson time to 'doing with ideas'. Although practical work was found to be effective in terms of getting students, in both primary and secondary schools, to do things with objects and materials in order to produce desired phenomena, much of this effectiveness appears to be attributable to the widespread use of 'recipe' style tasks. Furthermore, the relative effectiveness of practical work in providing an anchor for both primary and secondary school students' descriptive accounts of what they had done and observed appeared to reflect the care, effort and whole-class time devoted by teachers towards ensuring that their students were able to produce and observe the desired data and/or phenomena. This study also found that, in terms of the effectiveness of practical work in both 'doing' with, and 'learning' about, observables, there were no discernable differences between students in either primary or secondary schools.

Yet, despite the fact that both primary and secondary teachers included the learning of scientific ideas amongst their learning objectives there was little evidence, from interviews with teachers, to show that primary or secondary teachers explicitly planned how they wanted to get their students to learn about ideas. This was in marked contrast to the way in which their lesson plans and recipe style tasks explicitly made clear what they wanted the students to do with objects and how they wanted them to achieve this. The findings from this study suggest that practical tasks were generally ineffective in helping students to 'see' (Ogborn et al., 1996; Pardo \& Parker, 2010) the task from a scientific perspective, or to use scientific ideas as a means of making sense of their observations and/or data. Indeed, many of the teachers seemed, from their actions, to implicitly believe that the ideas that they claimed to want their students to learn would 'emerge' of their own accord from the observations or measurements, provided only that the students were able to produce these (cf. Solomon, 1994).

Whilst practical work in the laboratory offers important opportunities to link science concepts and theories with observations of phenomena (Hofstein \& Lunetta, 2004), for this to 
be successful requires that students must be helped not only to do and see what the teacher wants but, equally importantly, to think about their observations in a particular way (Gunstone, 1991). In such tasks students are likely to require assistance to use or develop the ideas that make sense of the activity and lead to learning. Tasks that are more effective will, we suggest, have this kind of 'scaffolding' built into their design. These finding suggest that whilst ideas about how to improve the effectiveness of practical work in terms of developing conceptual understanding have long been recognised - for example, the Predict-ObserveExplain (POE) task structure developed by White and Gunstone (1992) is a strategy designed to get students thinking about a particular practical task - teachers evidently remain either unaware of, or for some reason do not use, such approaches.

Two principal implications for practice arise from this study. First, there is a need for greater awareness amongst teachers about what students can realistically be expected to achieve, both in terms of 'doing' and 'learning', in practical lessons in science that seldom last more than 60 minutes. Indeed, in secondary schools, with arrival and registration at the beginning of the lesson and the need to pack away at the end, teaching time often does not exceed 45 minutes. Second, there is a need, as Millar (2004) has pointed out, for teachers to recognise that "[i]deas and explanations do not simply 'emerge' from data" (p. 3). If students are to learn from, rather than merely produce, phenomena, the widespread use of 'recipe' style tasks that were evident within this study needs to be replaced by a hypotheticodeductive view of learning in which teachers recognise that 'doing' with objects, materials and phenomena is unlikely to lead to the students 'learning' about scientific ideas and concepts unless they are also provided with what Wood, Bruner and Ross (1976) term a "scaffold" (p. 90). The process of scaffolding provides the initial means by which students are helped to 'see' the phenomena in the same 'scientific way' that the teacher 'sees' it (Ogborn et al., 1996; Pardo \& Parker, 2010). Indeed, as Lunetta (1998) has argued, "laboratory inquiry alone is not sufficient to enable students to construct the complex conceptual understandings of the contemporary scientific community. If students' understandings are to be changed towards those of accepted science, then intervention and negotiation with an authority, usually a teacher, is essential" (p. 252) where "laboratory inquiry' in this sense means essentially just following a recipe task. Students can be helped to develop the skills to engage in scientific argumentation (Berland \& Hammer, 2012). These ideas are not new but if, and it is a big 'if', practical work is to be made more effective in developing conceptual understanding, teachers' planning for lessons, when they include objectives that relate to learning about ideas, need to include explicitly, as Millar (2010) has argued, how they intend their students to learn about those ideas. Likewise, if the cognitive challenge of linking actions and observations with scientific ideas using scientific terminology is to be effectively addressed, secondary teachers need to be more aware, as many of their primary colleagues in this study already were, of the need to devote more practical lesson time to ensuring that students understand and are able to correctly use scientific terms and basic concepts relevant to the task. It is therefore to be hoped that the national IPWiS project, and other comparable projects in other countries, will, at the very least, raise science teachers' awareness of these ideas and, in particular, the need for practical work to become more 'hands-on and 'minds-on' than this baseline evaluation has found is currently the case.

\section{References}

Abrahams, I., \& Millar, R. (2008). Does practical work really work? A study of the effectiveness of practical work as a teaching and learning method in school science.

International Journal of Science Education, 30 (14), 1945-1969. 
Abrahams, I., \& Reiss, M. (2010). Effective practical work in primary science: The role of empathy. Primary Science, 113 (May/June), 26-27.

Abrahams, I., \& Saglam, M. (2010). A study of teachers' views on practical work in secondary schools in England and Wales, International Journal of Science Education 32 (6), 753-768.

Appleton, K. (1995). Science teachers' confidence to teach science: Is more science knowledge necessary to improve self-confidence. International Journal of Science Education, 17(3), 357-369.

Ball, S. J. (1984). Beachside reconsidered: Reflections on a methodological apprenticeship. In R. G. Burgess (Ed.), The research process in educational settings: Ten case studies (pp.69-96). Lewes: The Falmer Press.

Beatty, J. W., \& Woolnough, B. E. (1982). Practical work in 11-13 science: The context, type and aims of current practice. British Educational Research Journal, 8(1), 23-30.

Berland, L. K., \& Hammer, D. (2012). Framing for scientific argumentation. Journal of Research in Science Teaching, 49(1), 68-94.

Bennett, J. (2003). Teaching and learning science: A guide to recent research and its applications. London: Continuum.

Black, P. \& Wiliam, D. (1998). Assessment and classroom learning. Assessment in Education: Principles, Policy and Practice, 5(1), 7-74.

Bracht, G.H., \& Glass, G.V. (1968). The external validity of experiments. American Educational Research Journal, 5, 437-474.

Burron, B., James, M. L., \& Ambrosio, A. L. (1993). The effects of cooperative learning in a physical science course for elementary/middle level preservice teachers. Journal of Research in Science Teaching, 30, 697-707.

Cerini, B., Murray, I. \& Reiss, M. (2003) Student Review of the Science Curriculum: Major Findings, Planet Science, London. Available at http://www.planetscience.com/sciteach/review/Findings.pdf.

Chang, H.- P., \& Lederman, N. G. (1994). The effects of levels of co-operation within physical science laboratory groups on physical science achievement. Journal of Research in Science Teaching, 31, 167-181.

Clackson, S. G., \& Wright, D. K. (1992). An appraisal of practical work in science education. School Science Review, 74(266), 39-42.

Coffey, J. E., Hammer, D., Levin, D. M., \& Grant, T. (2011). The missing disciplinary substance of formative assessment. Journal of Research in Science Teaching, 48(10), 11091136.

Cohen, L., Manion, L., \& Morrison, K. (2000). Research methods in education. London: Routledge.

Crossley, M., \& Vulliamy, G. (1984). Case-study research methods and comparative education. Comparative Education, 20(2), 193-207.

Donnelly, J.F. (1998). The place of the laboratory in secondary science teaching. International Journal of Science Education, 20 (5), 585 - 596.

Donnelly, J., Buchan, A., Jenkins, E., Laws, P., \& Welford, G. (1996). Investigations by order: Policy, curriculum and science teachers' work under the Education Reform Act. Nafferton: Studies in Education.

Driver, R. (1975). The name of the game. School Science Review, 56(197), 800-805.

Edmondson, K.M., \& Novak, J.D. (1993). The interplay of scientific epistemological views, learning strategies, and attitudes of college students. Journal of Research in Science Teaching, 30(6), 547-559. 
Firestone, W. A., \& Herriott, R. E. (1984). Multisite qualitative policy research: Some design and implementation issues. In D. M. Fetterman (Ed.), Ethnography in educational evaluation (pp. 63-88). Beverly Hills, CA: Sage.

Gunstone, R. F. (1991). Reconstructing theory from practical experience. In Woolnough, B. E. (Ed.), Practical Science (pp. 67-77). Milton Keynes: Open University Press.

Harlen, W., \& Holroyd, C. (1997). Primary teachers' understanding of concepts of science: Impact on confidence and teaching. International Journal of Science Education, 19(1), 93-105.

Hart, C., Mulhall, P., Berry, A., Loughran, J., \& Gunstone, R. (2000). What is the purpose of this experiment? Or can students learn something from doing experiments? Journal of Research in Science Teaching, 37(7), 655-675.

Hewson, M., \& Hewson, P. (1983). Effect of instruction using student prior knowledge and conceptual change strategies on science learning. Journal of Research in Science Teaching, 20 (8), 731 - 743.

Hodson, D. (1991). Practical work in science: Time for a reappraisal. Studies in Science Education, 19, 175-184.

Hofstein, A., \& Lunetta, V. N. (2004). The laboratory in science education: Foundations for the twenty-first century. Science Education, 88, 28-54.

Hofstein, A., \& Lunetta, V. N. (1982). The role of the laboratory in science teaching: Neglected aspects of research. Review of Educational Research, 52, 201-218.

Jackman, L. E., \& Moellenberg, W. P. (1987). Evaluation of three instructional methods for teaching general chemistry. Journal of Chemical Education, 64, 794-796.

Kerr, J. F. (1964). Practical work in school science. Leicester, UK: Leicester

Kind, P. M., Kind, V., Hofstein, A., \& Wilson, J. (2011) Peer argumentation in the school science laboratory - Exploring effects of task features. International Journal of Science Education, 33 (18), 2577-2558

Lazarowitz, R., \& Tamir, P. (1994). Research on using laboratory instruction in science. In Gabel, D. L. (Ed.), Handbook of research on science teaching and learning. New York: Macmillan.

Lunetta, V. N. (1998). The school science laboratory: Historical perspectives and contexts for contemporary teaching. In K. Tobin \& B. Fraser (Eds), International handbook of science education (Part 1, pp. 249-262). Dordrecht, The Netherlands: Kluwer.

Lunetta, V. N., Hofstein, A., \& Clough, M. P. (2007) Learning and teaching in the school science laboratory: an analysis of research, theory, and practice. In S. K. Abell \& N. G. Lederman (Eds), Handbook of Research on Science Education (pp. 393-441). Mahwah, NJ.: Lawrence Erlbaum.

Lunetta, V. N., \& Tamir, P. (1979). Matching lab activities with teaching goals. The Science Teacher, 46(5), 22-24.

Millar, R. (2011). Practical work. In J. Osborne \& J. Dillon (Eds). Good practice in science teaching: What research has to say (pp.108-134). Maidenhead: Open University Press.

Millar, R. (2010). Analysing practical science activities to assess and improve their effectiveness. Hatfield: Association for Science Education.

Millar, R. (2004). The role of practical work in the teaching and learning of science. Paper prepared for the meeting: High school science laboratories: Role and vision. Washington DC.: National Academy of Sciences.

Millar, R. (2002). Thinking about practical work. In S. Amos \& R. Booka (Eds), Aspects of teaching secondary science: Perspectives on practice. London: Routledge Falmer. 
Millar, R. (1998). 'Rhetoric and reality: What practical work in science education is really for'. In J. Wellington (Ed.), Practical work in school science: Which way now?, London: Routledge.

Millar, R., \& Abrahams, I. (2009). Practical work: Making it more effective. School Science Review, 91 (334), 59-64.

Millar, R., Le Maréchal, J.-F., \& Tiberghien, A. (1999). 'Mapping' the domain: Varieties of practical work. In J. Leach \& A. Paulsen (Eds), Practical work in science education-Recent research studies (pp. 33-59). Roskilde/Dordrecht, The Netherlands: Roskilde University Press/Kluwer.

Moeed, A. (2011). Successful science learning from practical work. School Science Review. 93(343), 121-126.

Mulopo, M. M., \& Fowler, H. S. (1987). Effects of traditional and discovery instructional approaches on learning outcomes for learners of different intellectual development: A study of chemistry students in Zambia. Journal of Research in Science Teaching, 24 (3), 217-227.

Ogborn, J., Kress, G., Martins, I., \& McGillicuddy, K. (1996). Explaining science in the classroom. Buckingham, UK: Open University Press.

Osborne, J. (1993). Alternatives to practical work. School Science Review, 75(271), 117-123.

Pardo, P., \& Parker, J. (2010). The inquiry flame: scaffolding for scientific inquiry through experimental design. The Science Teacher, 77(8), 44-49.

Richmond, G., \& Striley, J. (1996). Making meaning in classrooms: Social processes in small group discourse and scientific knowledge building. Journal of Research in Science Teaching, 33(8), 839-858.

Shaughnessy, J. J., \& Zechmeister, E. B. (1985). Research methods in psychology. New York: Knopf.

Solomon, J. (1994). The laboratory comes of age. In R. Levinson (Ed.). Teaching science (pp. 7-21). London: Routledge.

Stenhouse, L. (1984). Library access, library use and user education in academic sixth forms: An autobiographical account. In R. G. Burgess (Ed.), The research process in educational settings: Ten case studies (pp. 211-234). Lewes, UK: Falmer Press.

Tiberghien, A. (2000). Designing teaching situations in the secondary school. In R. Millar, J. Leach \& J. Osborne (Eds), Improving science education: The contribution of research (pp. 27-47). Buckingham, UK: Open University Press.

Walker, R. (1980). The conduct of educational case studies: Ethics, theory and procedures. In W.B. Dockrell, W.B. \& D. Hamilton (Eds), Rethinking educational research. Sevenoaks, UK: Hodder and Stoughton.

Watson, J. R., Prieto, T., \& Dillon, J. (1995). The effect of practical work on students' understanding of combustion. Journal of Research in Science Teaching, 32 (5), 487-502.

Wellington, J. (1998). Practical work in science. Time for a reappraisal. In J.

Wellington (Ed.), Practical work in school science: Which way now? (pp. 3-15). London: Routledge.

White, R.T. (1996). The link between the laboratory and learning. International Journal of Science Education, 18 (7), 761-774.

White, R. T. (1988). Learning science. Oxford, UK: Blackwell.

White, R. T. (1979). Relevance of practical work to comprehension of physics. Physics Education, 14, 384-387.

White, R. T., \& Gunstone, R. F. (1992). Probing Understanding. London: Falmer Press 
Wood, D., Bruner, J. S., \& Ross, G. (1976). The role of tutoring in problem solving. Journal of Child Psychology and Psychiatry, 17, 89-100. 
Table 1. A 2x2 effectiveness matrix for practical work

\begin{tabular}{lll}
\hline $\begin{array}{l}\text { A task is } \\
\text { effective }\end{array}$ & \multicolumn{1}{c}{$\begin{array}{c}\text { in the domain of observables } \\
\text { (Domain o) }\end{array}$} & \multicolumn{1}{c}{$\begin{array}{c}\text { in the domain of ideas } \\
\text { (Domain i) }\end{array}$} \\
\hline $\begin{array}{l}\text { at level 1 } \\
\text { (what } \\
\text { students do) }\end{array}$ & $\begin{array}{l}\text { If students can set up the } \\
\text { equipment and operate it in such a } \\
\text { manner as to undertake what the } \\
\text { teacher intended. }\end{array}$ & $\begin{array}{l}\text { If students can think about the task } \\
\text { using the ideas and scientific } \\
\text { vocabulary intended by the teacher. }\end{array}$ \\
\hline $\begin{array}{l}\text { at level 2 } \\
\text { (what } \\
\text { students }\end{array}$ & $\begin{array}{l}\text { If students can discover patterns } \\
\text { within their observations/data and } \\
\text { learn) }\end{array}$ & $\begin{array}{l}\text { If students understand their } \\
\text { observations/data by being able to link } \\
\text { procedure used and in future set } \\
\text { them, using the ideas and vocabulary }\end{array}$ \\
\end{tabular}


Table 2 The $2 \times 2$ effectiveness matrix for a practical task involving an investigation of the chromatographic separation of colours in dyes

\begin{tabular}{|c|c|c|}
\hline $\begin{array}{l}\text { A task is } \\
\text { effective }\end{array}$ & $\begin{array}{l}\text { in the domain of observables } \\
\text { (Domain o) }\end{array}$ & in the domain of ideas (Domain i) \\
\hline $\begin{array}{l}\text { at level } 1 \\
\text { (what } \\
\text { students do) }\end{array}$ & $\begin{array}{l}\text { If students can: construct a } \\
\text { separation column to match the } \\
\text { provided instructions; observe how } \\
\text { a drop of dye placed on the filter } \\
\text { paper spreads out as liquid seeps up } \\
\text { the paper, so that several spots or } \\
\text { streaks can be seen. }\end{array}$ & $\begin{array}{l}\text { If students can talk about different } \\
\text { substances moving up the paper at } \\
\text { different speeds; several spots } \\
\text { implying several substances; dyes as } \\
\text { mixtures of substances. }\end{array}$ \\
\hline $\begin{array}{l}\text { at level } 2 \\
\text { (what } \\
\text { students } \\
\text { learn) }\end{array}$ & $\begin{array}{l}\text { If students can set up and use a } \\
\text { chromatographic separation } \\
\text { column. Students state that } \\
\text { separated colours are different dyes } \\
\text { that made up their initial dye; this } \\
\text { can be used to separate a mixture of } \\
\text { dyes into its components; that the } \\
\text { pattern from an unknown dye can } \\
\text { be compared with that of a known } \\
\text { one to help identify the unknown } \\
\text { one. }\end{array}$ & $\begin{array}{l}\text { If students can state that: different } \\
\text { substances move up a } \\
\text { chromatography column at different } \\
\text { speeds; this can be used to see if } \\
\text { something contains more than one } \\
\text { substance; this can be used to } \\
\text { separate the components substances } \\
\text { in a mixture; that the chromatogram } \\
\text { of an unknown sample can be } \\
\text { compared with those of known } \\
\text { samples to see if they contain the } \\
\text { same component substances. }\end{array}$ \\
\hline
\end{tabular}


Table 3. Primary schools: Practical tasks observed and teacher experience and specialism

\begin{tabular}{|c|c|c|c|c|c|}
\hline $\begin{array}{l}\text { Primary } \\
\text { school } \\
\text { code }\end{array}$ & $\begin{array}{l}\text { Student } \\
\text { age } \\
\text { range } \\
\text { (years) }\end{array}$ & $\begin{array}{l}\text { Number of } \\
\text { students }\end{array}$ & $\begin{array}{l}\text { Teachers' } \\
\text { teaching } \\
\text { experience } \\
\text { (years) }\end{array}$ & $\begin{array}{l}\text { Teachers' } \\
\text { subject } \\
\text { specialism }\end{array}$ & Practical task content \\
\hline BRM & $9-11$ & 28 & 10 & Maths & Dissolving - comparing solvents \\
\hline COD & $7-9$ & 28 & 9 & Biology & Insulation - properties of materials \\
\hline HEE & $4-7$ & 28 & 10 & Education & Keeping healthy - comparing soaps \\
\hline HIS & $7-8$ & 26 & 10 & English & Materials - properties \\
\hline MIL & $10-11$ & 30 & 4 & Maths & Friction - comparing surfaces \\
\hline SOS & $9-10$ & 29 & 17 & History & Moon craters - factors affecting size \\
\hline SWS & $7-9$ & 28 & 3 & Business Studies & Measuring arms - body growth \\
\hline UPL & $8-9$ & 27 & 1 & French & Friction - comparing surfaces \\
\hline WAE & $9-11$ & 30 & 4 & Science & Variables - bicarbonate boats \\
\hline WEE & $7-9$ & 26 & 4 & History & States of matter - their properties \\
\hline
\end{tabular}


Table 4. Secondary schools: Practical tasks observed and teacher experience and specialism

\begin{tabular}{|c|c|c|c|c|c|}
\hline $\begin{array}{l}\text { Secondary } \\
\text { school } \\
\text { code }\end{array}$ & $\begin{array}{l}\text { Student } \\
\text { age } \\
\text { range } \\
\text { (years) }\end{array}$ & $\begin{array}{l}\text { Number } \\
\text { of } \\
\text { students }\end{array}$ & $\begin{array}{l}\text { Teachers' } \\
\text { teaching } \\
\text { experience } \\
\text { (years) }\end{array}$ & $\begin{array}{l}\text { Teachers' } \\
\text { degree } \\
\text { specialism }\end{array}$ & Practical task content \\
\hline ALY & $13-14$ & 31 & 28 & Chemistry & $\begin{array}{l}\text { Fermentation - testing for } \\
\text { alcohol }\end{array}$ \\
\hline ANO & $17-18$ & 28 & 7 & Physics & $\begin{array}{l}\text { Electric motors - role of } \\
\text { parts }\end{array}$ \\
\hline ARE & $16-17$ & 30 & 9 & Chemistry & $\begin{array}{l}\text { Thermal decomposition - } \\
\text { gas production }\end{array}$ \\
\hline CAN & $13-14$ & 30 & 9 & Bio./Chem. & $\begin{array}{l}\text { Reaction times - the fastest } \\
\text { sense }\end{array}$ \\
\hline CHS & $12-13$ & 30 & 11 & Biology & $\begin{array}{l}\text { Eyes - structure by } \\
\text { dissection }\end{array}$ \\
\hline $\mathrm{COE}$ & $13-14$ & 27 & 14 & Psychology & $\begin{array}{l}\text { Starch production - factors } \\
\text { that affect }\end{array}$ \\
\hline $\mathrm{CRN}$ & $12-13$ & 30 & 16 & Psychology & $\begin{array}{l}\text { Soil samples - comparing } \\
\text { absorbency }\end{array}$ \\
\hline EAK & $14-15$ & 24 & 25 & Chemistry & $\begin{array}{l}\text { Absorbency - comparing } \\
\text { materials }\end{array}$ \\
\hline GLS & $11-12$ & 29 & 1 & Forensic Sc. & $\begin{array}{l}\text { Absorbency - comparing } \\
\text { materials }\end{array}$ \\
\hline $\mathrm{HAN}$ & $13-14$ & 28 & 2 & Physics & $\begin{array}{l}\text { Levers and pivots - Force } \mathrm{x} \\
\text { distance }\end{array}$ \\
\hline ILD & $16-17$ & 29 & 10 & Biology & Stomata - structure \\
\hline LAY & $13-14$ & 29 & 7 & Biology & Friction - factors affecting \\
\hline MOT & $12-13$ & 27 & 16 & Zoology & $\begin{array}{l}\text { Insulation - properties of } \\
\text { materials }\end{array}$ \\
\hline NOY & $13-14$ & 29 & 2 & Biology & $\begin{array}{l}\text { Reactivity of metals - word } \\
\text { equations }\end{array}$ \\
\hline SHS & $11-12$ & 27 & 3 & Biology & $\begin{array}{l}\text { Starch production - factors } \\
\text { that affect }\end{array}$ \\
\hline SOS & $11-12$ & 30 & 6 & Biology & $\begin{array}{l}\text { Energy in food - Joule } \\
\text { heating tests }\end{array}$ \\
\hline SAS & $15-16$ & 30 & 4 & $\begin{array}{l}\text { Pharmacolo } \\
\text { gy }\end{array}$ & $\begin{array}{l}\text { Chromatography - } \\
\text { separation of inks }\end{array}$ \\
\hline SWY & $12-13$ & 32 & 1 & Chemistry & $\begin{array}{l}\text { Magnetic permeability of } \\
\text { materials }\end{array}$ \\
\hline UPS & $14-15$ & 29 & 18 & Biology & $\begin{array}{l}\text { DNA - extraction from } \\
\text { cheek cells }\end{array}$ \\
\hline WEY & $15-16$ & 28 & 24 & Biology & Leaf structure - stomata \\
\hline
\end{tabular}


Table 5. Primary schools: Allocation of whole class time to different aspects of the lesson Percentage of whole-class lesson time Percentage of lesson spent by teacher on discussing and/or time spent by students

\begin{tabular}{|c|c|c|c|}
\hline $\begin{array}{l}\text { Primary } \\
\text { School }\end{array}$ & $\begin{array}{l}\text { What to do with } \\
\text { objects or materials }\end{array}$ & $\begin{array}{l}\text { Ideas and models } \\
\text { to be used }\end{array}$ & $\begin{array}{l}\text { Manipulating objects } \\
\text { and materials }\end{array}$ \\
\hline BRM & 13 & 30 & 30 \\
\hline COD & 10 & 25 & 45 \\
\hline HEE & 17 & 27 & 27 \\
\hline HIS & 8 & 32 & 25 \\
\hline MIL & 20 & 25 & 32 \\
\hline SOS & 13 & 22 & 32 \\
\hline SWS & 11 & 26 & 20 \\
\hline UPL & 17 & 19 & 33 \\
\hline WAE & 7 & 21 & 9 \\
\hline WEE & 9 & 26 & 41 \\
\hline Average & 13 & 25 & 29 \\
\hline
\end{tabular}


Table 6. Secondary schools: Allocation of whole class time to different aspects of the lesson Percentage of whole-class lesson time Percentage of lesson time spent by teacher on discussing and/or spent by students demonstrating

\begin{tabular}{lcll} 
Secondary & $\begin{array}{l}\text { What to do with } \\
\text { School }\end{array}$ & $\begin{array}{l}\text { Ideas and models } \\
\text { objects or materials }\end{array}$ & $\begin{array}{l}\text { Manipulating objects and } \\
\text { to be used }\end{array}$ \\
\hline ALY & 26 & 4 & 55 \\
ANO & 5 & 25 & 54 \\
ARE & 2 & 0 & 39 \\
CAN & 10 & 3 & 39 \\
CHS & 19 & 15 & 42 \\
COE & 23 & 3 & 33 \\
CRN & 17 & 6 & 47 \\
EAT & 32 & 10 & 52 \\
GLS & 15 & 17 & 36 \\
HAN & 15 & 17 & 33 \\
ILD & 15 & 8 & 60 \\
LAY & 21 & 20 & 40 \\
MOT & 26 & 10 & 36 \\
NOY & 13 & 17 & 43 \\
SHS & 14 & 11 & 47 \\
SOS & 16 & 19 & 31 \\
SAS & 20 & 7 & 30 \\
SWY & 10 & 12 & 24 \\
UPS & 17 & 7 & 49 \\
WEY & 20 & 14 & 45 \\
\hline Average & 17 & 11 & 42 \\
\hline & & & \\
\hline
\end{tabular}

